Article

\title{
The Content of Phenolic Acids and Flavonols in the Leaves of Nine Varieties of Sweet Potatoes (Ipomoea batatas L.) Depending on Their Development, Grown in Central Europe
}

\author{
Barbara Krochmal-Marczak ${ }^{1, *(1)}$, Tomasz Cebulak ${ }^{2}$, Ireneusz Kapusta ${ }^{2}{ }^{\oplus}$, Jan Oszmiański ${ }^{3}{ }^{(0)}$, \\ Joanna Kaszuba ${ }^{2}$ (D) and Natalia Żurek ${ }^{2}$ (D) \\ 1 Department of Plant Production and Food Safety, Carpathian State College in Krosno, 38-400 Krosno, Poland \\ 2 Department of Food Technology and Human Nutrition, Institute of Food Technology and Nutrition, \\ College of Natural Sciences, University of Rzeszów, 35-601 Rzeszów, Poland; tomcebulak@gmail.com (T.C.); \\ ikapusta@ur.edu.pl (I.K.); jkaszuba@ur.edu.pl (J.K.); nataliazurek7@gmail.com (N.Ż.) \\ 3 Department of Fruit, Vegetable and Plant Nutraceutical Technology, Faculty of Biotechnology and Food \\ Science, Wrocław University of Environmental and Life Science, 51-630 Wrocław, Poland; \\ jan.oszmianski@up.wroc.pl \\ * Correspondence: barbara.marczak@pwsz.krosno.pl; Tel.: +4813-437-5580
}

Received: 13 July 2020; Accepted: 28 July 2020; Published: 30 July 2020

check for updates

\begin{abstract}
The aim of the study was the qualitative and quantitative analysis of the bioactive components present in the leaves of 9 sweet potato cultivars grown in the moderate climate in Poland, which were harvested at different growth stages according to the $\mathrm{BBCH}$ (Biologische Bundesanstalt, Bundessortenamt und Chemische Industrie) scale $(14,51,89)$. It was found that sweet potato leaves contained 7 polyphenolic compounds, including 5 chlorogenic acids-neochlorogenic acid (5-CQA), chlorogenic acid (3-CQA), 4-cryptochlorogenic acid (4-CQA), 34-di-O-caffeoylqunic acid (3,4-CQA), 3,5-di-O-caffeoylqunic acid (3,5-CQA) — and 2 flavonoids, quercetin-3-O-galactoside (Q-3-GA) and quercetin-3-O-glucoside (Q-3-GL). Their content depended on the genotype of the examined cultivars and on the stage of leaf development. The mean content of the identified polyphenolic compounds in the examined cultivars ranged from 148.2 to $14.038 .6 \mathrm{mg} / 100 \mathrm{~g}^{-1} \mathrm{DM}$ for the leaves harvested at growth stage 14 according to the $\mathrm{BBCH}$ scale. In the case of leaves harvested at $\mathrm{BBCH}$ stage 51 , the concentration of polyphenolic compounds ranged from 144.76 to $5026.8 \mathrm{mg} / 100 \mathrm{~g}^{-1} \mathrm{DM}$ and at $\mathrm{BBCH}$ stage 89 from 4078.1 to $11.183 .5 \mathrm{mg} / 100 \mathrm{~g}^{-1} \mathrm{DM}$. The leaves of the Carmen Rubin cultivar collected at stage 14 contained the highest amount of polyphenolic compounds, while Okinava leaves had the highest amount of these compounds at stage 51. The highest content of polyphenolic compounds in leaves at $\mathrm{BBCH}$ growth stage 89 was found in the Radiosa variety. The highest concentration levels were found for 3-CQA at all stages of leaf development. Significant correlations between polyphenol content and antioxidant activity measured by 2,2'-azino-bis(3-ethylbenzothiazoline-6-sulfonic acid (ABTS), 2,2-diphenyl-1-picrylhydrazyl (DPPH), and ferric reducing/antioxidant power (FRAP) were found. The results of this experiment revealed that the growth stages and genetic properties of cultivars have a very significant influence on the content of phenolic acids and flavonols in sweet potato leaves. The results are innovative and can have a practical application, as the knowledge of the content of the substances under study makes it possible to determine the optimal management practice of sweet potato leaf harvest in order to obtain more top-quality raw material.
\end{abstract}

Keywords: sweet potatoes; leaves; varieties; $\mathrm{BBCH}$; phenolic acids; flavonols; ABTS; DPPH; FRA; antioxidant activity 


\section{Introduction}

Climate changes in Central Europe caused by increasing temperatures and decreasing precipitation can result in a loss or decrease of the significance of the presently cultivated plant species; therefore, it seems necessary to start growing alternative plants from the tropical climate and adapt them to new climate and soil conditions [1]. Such a species can be sweet potato (Ipomoea batatas L.), which is a plant from the tropical and subtropical climate whose usable parts are tubers and leaves. Sweet potato belongs to high-yield vegetable plants [2]. On a global scale, it ranks fifth after the cultivation of rice, wheat, corn, and cassava [3]. It is grown in all subtropical countries in America, Africa, and Asia, and it is the most popular of all tropical and subtropical tubers in the world [4]. In terms of human consumption, it is the most important edible plant in the world, in particular in Africa, parts of Asia, and the Pacific Islands. In suitable conditions, it can also be cultivated in the temperate zone $[5,6]$. The usable parts are underground tubers and leaves, which-in various parts of the world-are the raw material for the preparation of soups, teas, and salads, as well as grown as a raw material of the pharmaceutical and food industries [7]. Research by Dinu et al. [8] shows that sweet potato leaves have the highest antioxidant potential among leafy green vegetables. Research by Ishida et al. [9] and Sun et al. [10] showed the high nutritional value of sweet potato leaves expressed as the amount of minerals ( $\mathrm{Ca}, \mathrm{P}, \mathrm{Mg}, \mathrm{Na}, \mathrm{K}, \mathrm{Fe}, \mathrm{Cu}, \mathrm{Zn})$, soluble fibre, vitamins (C, E, B1, B2, B6, niacin, biotin, carotene, pantothenic acid), and protein. The content of all of the above-mentioned components was much higher than in sweet potato tubers and stems, whereas the INQ (the Index of Nutrition Quality illustrating nutrient density) for protein, fibre, and most minerals was above 2 (an index of 1 means a well-balanced product in terms of the analysed ingredient). Johnson and Pace [11] studied sweet potato leaves and found a high level of unsaturated fatty acids, mainly linolenic and $\alpha$-linolenic acid. According to research by Neel and Fant [12], sweet potato leaves demonstrate high biological activity expressed in high antioxidant activity and the ability to compensate for vitamin A deficiency. According to a number of authors, with a high content of polyphenols and vitamins C, B1, B2, and B6, sweet potato leaves help scavenge free radicals, and they have anti-ageing, anti-cancer, antibacterial, anti-inflammatory, antihypertensive and antidiabetic (type 2 diabetes) properties [13-16]. In their research, Kurata et al. [17] showed that polyphenolic compounds isolated from sweet potato leaves are very effective in reducing the increase of gastric cancer cells (Kato III), colorectal cancer cells (DLD-1), and leukaemia cells (HL-60). In addition, sweet potato leaves are rich in lutein, which is used to prevent macular degeneration [18]. However, the health benefits of plant raw materials depend to a large extent on the level of bioactive ingredients, which in turn depend on plant adaptation to the environmental conditions during the establishment, growth stages, and genetic properties of cultivars [7]. Therefore, the aim of this paper was to determine the influence of leaf growth stages and cultivar genotype on the content of phenolic acids and flavonols properties in the leaves of nine sweet potato cultivars grown in central Europe.

\section{Results and Discussions}

\subsection{Identification of Phenolic Compounds in Sweet Potato Leaves}

The identification of phenolic acids and flavonoids was based on the characteristics of ultraviolet spectra, mass spectra (UPLC)-PDA-MS/MS Waters ACQUITY system (Waters, Milford, MA, USA) and benchmark substances (Table 1) [19-21]. The polyphenolic compound profile was determined on the basis of UV-VIS adsorption maxima spectra, $\mathrm{m} / \mathrm{z}$ mass-to-charge ratio, and fragmentation ions achieved from collision-induced dissociation (CID). The results are presented in Table 1. 
Table 1. Characterisation of phenolics compounds from sweet potato extracts collected from the HPLC column and analysed by UV-VIS, HPLC, and LC/MS. 3-CQA: chlorogenic acid, 5-CQA: neochlorogenic acid, 4-CQA: 4-cryptochlorogenic acid, 3,4-diCQA: 3,4-di-O-caffeoylqunic acid, 3,5-diCQA: 3,5-di-O-caffeoylqunic acid.

\begin{tabular}{|c|c|c|c|c|c|}
\hline $\begin{array}{l}\text { Peak } \\
\text { No. }\end{array}$ & $\begin{array}{c}\mathrm{Rt} \\
(\mathrm{min})\end{array}$ & $\begin{array}{c}\text { UV-Vis } \\
\text { nm }\end{array}$ & $\begin{array}{c}{[\mathbf{M}-\mathbf{H}]^{-}} \\
(m / z)\end{array}$ & $\begin{array}{l}\text { Fragment Ion } \\
\qquad(m / z)\end{array}$ & Compounds \\
\hline \multicolumn{6}{|c|}{ phenolics acid } \\
\hline 1 & 2.335 & $240 / 298 / 327$ & 353 & $191,179,135$ & 3-CQA \\
\hline 2 & 2.960 & $241 / 298 / 328$ & 353 & 191 & 5-CQAA \\
\hline 3 & 3.139 & $244 / 298 / 326$ & 353 & $173,179,191,135,155,161$ & 4-CQA \\
\hline 6 & 5.153 & $240 / 298 / 326$ & 515 & $135,155,161,173,179,191,353$ & 3,4-diCQA \\
\hline 7 & 5.275 & $239 / 298 / 328$ & 515 & $\begin{array}{l}\text { 135,179,191,335,353 } \\
\text { flavonols }\end{array}$ & 3,5-diCQA \\
\hline 4 & 4.727 & $256 / 265 / 354$ & 463 & $151,179,255,271,300,301$ & Quercetin-3-O-galactoside \\
\hline 5 & 4.763 & $256 / 265 / 354$ & 463 & $151,179,255,271,300,301$ & Quercetin-3-O-glucoside \\
\hline
\end{tabular}

In total, 7 polyphenolic compounds from two categories were identified: phenolic acids and flavonols. Within the first category, 5 hydroxycinnamic-acid derivatives were found. Peaks 1, 2, and 3 were characterised by the same $m / z$ value of $[\mathrm{M}-\mathrm{H}]^{-} \mathrm{m} / \mathrm{z} 353$, whereas the fragmentation ion spectrum included two characteristic fragments with a mass of 179 and 191 respectively, pointing to the presence of caffeic and quinic acid radicals in the particle. The compounds were identified as esters of caffeoylquinic acid: 3-CQA, 5-CQA, and 4-CQA, which are usually called chlorogenic acid $(\mathrm{Rt}=2.335)$, neochlorogenic acid $(\mathrm{Rt}=2.960)$, and 4 -cryptochlorogenic acid $(\mathrm{Rt}=3.139)$. Peaks 6 and 7 had a pseudo molecular $m / z$ peak of 515 , which was 162 units larger than caffeoylquinic esters. The registered mass loss due to the parent peak fragmentation indicated the presence of additional caffeic acid radicals. The compounds were identified as dicaffeoylquinic esters: 3,4-diCQA and 3,5-diCQA, respectively. The other peaks 4 and 5 belonged to the flavonol group. Those peaks were characterised by the same pseudo molecular $\mathrm{m} / \mathrm{z}$ peak of 463 . The conducted fragmentation revealed a fragmentation ion 301 that is characteristic for quercetin, resulting from the formation of fragment 162, which is characteristic for a hexose particle. Therefore, peaks 4 and 5 were categorised as quercetin-3-O-galactoside and quercetin-3-O-glucoside, respectively.

\subsection{Antioxidant Activity of Sweet Potato Leaves Depending on BBCH Growth Stage}

According to a number of authors, the climate conditions during vegetation determine the intensity of abiotic stress factors (UV radiation, temperature, precipitation), which are the main factor influencing the synthesis of secondary metabolites, whose level depends on the vegetative parts of the plant and its growth stage [22,23]. According to Padda and Picha [24], the most secondary metabolites are synthesised in the leaf blade. Research by Jang and Koh [25] and Hue et al. [26] showed that another factor differentiating the antioxidant activity is the genetic variability of cultivars. The antioxidant activity of sweet potato leaf extracts depending on the $\mathrm{BBCH}$ (Biologische Bundesanstalt, Bundessortenamt und Chemische Industrie) growth stage measured with 2,2'-azino-bis(3-ethylbenzothiazoline-6-sulfonic acid $\left(\mathrm{ABTS}^{\circ+}\right)$, 2,2-diphenyl-1-picrylhydrazyl (DPPH), and ferric reducing/antioxidant power (FRAP) assays is listed in Table 2. 
Table 2. Antioxidant activity and correlation coefficients for sweet potato (Ipomoea batatas L. [Lam.]) leaf extracts measured by tests ABTS ${ }^{\circ+}$, FRAP and DPPH [ $\mu$ mol TE (Trolox)/100 g ${ }^{-1}$ DM.].

\begin{tabular}{|c|c|c|c|c|c|c|c|c|c|}
\hline Varieties & Okinava & $\begin{array}{c}\text { Carmen } \\
\text { Rubin }\end{array}$ & Radiosa & $\begin{array}{l}\text { White } \\
\text { Triumph }\end{array}$ & Malokai & Purple & Beauregard & Jewel & $\begin{array}{l}\text { Satsumo } \\
\text { Imo }\end{array}$ \\
\hline \multicolumn{10}{|c|}{ Harvest time in phase 14 according to the $\mathrm{BBCH}$ scale } \\
\hline $\begin{array}{c}\text { Polyphenols } \\
\mathrm{mg} \cdot 100 \mathrm{~g}^{-1} \mathrm{DM} .\end{array}$ & 14.0386 & 1767.8 & 1604.9 & 148.2 & 962.1 & 383.1 & 1426.8 & 5251 & 800.91 \\
\hline ABTS & 138.16 & 52.67 & 51.44 & 24.24 & 30.03 & 30.82 & 41.45 & 90.53 & 26.97 \\
\hline $\begin{array}{l}\text { Correlation } \\
\text { coefficient }\end{array}$ & -0.838 & -0.994 & -0.600 & -0.997 & 0.999 & 0.993 & 0.995 & 0.675 & 0.141 \\
\hline $\mathrm{DPPH}$ & 190.75 & 46.63 & 49.75 & 18.55 & 22.73 & 28.17 & 39.93 & 117.46 & 28.49 \\
\hline $\begin{array}{l}\text { Correlation } \\
\text { coefficient }\end{array}$ & -0.958 & 0.755 & 0.379 & 0.999 & 0.978 & 0.999 & 0.931 & 0.711 & -0.362 \\
\hline FRAP & 551 & 144.5 & 147.3 & 52.8 & 72.6 & 95.4 & 115.6 & 326.3 & 86.4 \\
\hline $\begin{array}{l}\text { Correlation } \\
\text { coefficient }\end{array}$ & -0.974 & 0.839 & -0.286 & 0.997 & 0.986 & 0.999 & 0.999 & 0.597 & -0.565 \\
\hline \multicolumn{10}{|c|}{ Harvest time in phase 51 according to the $\mathrm{BBCH}$ scale } \\
\hline $\begin{array}{c}\text { Polyphenols } \\
\mathrm{mg} \cdot 100 \mathrm{~g}^{-1} \mathrm{DM} .\end{array}$ & 1500.8 & 829.2 & 5026.8 & 760.8 & 144.76 & 2003.6 & 2211.3 & 873.1 & 351.35 \\
\hline ABTS & 41.49 & 27.72 & 63.39 & 26.48 & 26.49 & 11.4 & 55.77 & 30.52 & 12.44 \\
\hline $\begin{array}{l}\text { Correlation } \\
\text { coefficient }\end{array}$ & 0.705 & 0.998 & 0.993 & 0.664 & 0.664 & 0.999 & -0.395 & 0.999 & -0.394 \\
\hline DPPH & 105.64 & 50.59 & 187.39 & 47.6 & 47.60 & 10.47 & 122.56 & 58.63 & 38.66 \\
\hline $\begin{array}{l}\text { Correlation } \\
\text { coefficient }\end{array}$ & 0.658 & 0.987 & 0.974 & -0.956 & -0.956 & 0.998 & -0.369 & 0.999 & -0.719 \\
\hline FRAP & 283.46 & 172.56 & 617.43 & 138.5 & 138.58 & 28.47 & 415.43 & 168.45 & 131.34 \\
\hline $\begin{array}{c}\text { Correlation } \\
\text { coefficient }\end{array}$ & 0.537 & 0.999 & 0.996 & 0.999 & 0.999 & 0.999 & -0.381 & 0.998 & -0.772 \\
\hline \multicolumn{10}{|c|}{ Harvest time in phase 89 according to the $\mathrm{BBCH}$ scale } \\
\hline $\begin{array}{c}\text { Polyphenols } \\
\mathrm{mg} \cdot 100 \mathrm{~g}^{-1} \mathrm{DM} .\end{array}$ & 7059.6 & 6333.4 & 11.1835 & 4802.4 & 5193.3 & 4078.1 & 9303.5 & 7731.2 & 5326.5 \\
\hline ABTS & 93.35 & 108.6 & 126.52 & 112.65 & 90.62 & 101.52 & 113.6 & 108.6 & 89.46 \\
\hline $\begin{array}{l}\text { Correlation } \\
\text { coefficient }\end{array}$ & 0.888 & 0.537 & 0.805 & 0.301 & 0.756 & 0.776 & -0.141 & 0.980 & 0.492 \\
\hline DPPH & 110.62 & 145.6 & 197.43 & 124.81 & 114.59 & 109.72 & 171.7 & 147.3 & 65.77 \\
\hline $\begin{array}{l}\text { Correlation } \\
\text { coefficient }\end{array}$ & 0.656 & 0.785 & 0.813 & 0.227 & 0.776 & 0.665 & -0.352 & 0.954 & 0.549 \\
\hline FRAP & 308.0 & 455.3 & 636.31 & 382.0 & 385.0 & 334.42 & 558.4 & 462.4 & 195.61 \\
\hline $\begin{array}{l}\text { Correlation } \\
\text { coefficient }\end{array}$ & 0.817 & -0.678 & 0.367 & 0.327 & 0.720 & 0.773 & -0.272 & 0.962 & -0.201 \\
\hline
\end{tabular}

The results show that the variability range of antioxidant activity depends on the cultivar and leaf growth stage. In the first harvest date at $\mathrm{BBCH}$ stage 14, the highest antioxidant activity in $\mathrm{ABTS}{ }^{\circ+}$, DPPH, and FRAP assays was found in the leaves of the Okinava sweet potato and the lowest was found in the White Triumph cultivar. The decrease of antioxidant activity of leaves among sweet potato cultivars, from the highest to the lowest, was the following: Okinava $>$ Jewel $>$ Carmen Rubin $>$ Radiosa $>$ Beauregard $>$ Purple $>$ Molokai $>$ Satsumo Imo $>$ White Triumph. Meanwhile, at this stage of leaf harvest, there were significant correlations between the applied ABTS ${ }^{\circ+}$, DPPH, and FRAP assays and total polyphenolic compounds (Table 2). The antioxidant potential of leaves harvested at $\mathrm{BBCH}$ stage 51 was ordered in the following way: Radiosa $>$ Beauregard $>$ Purple $>$ Okinava $>$ Jewel $>$ Carmen Rubin $>$ White Triumph $>$ Satsumo Imo $>$ Malokai. In the FRAP assay, the antioxidant activity ranged from $617.43 \mu \mathrm{mol}$ TE (Trolox) $/ 100 \mathrm{~g}$ DM in the Radiosa leaf extract to $28.47 \mu \mathrm{mol}$ TE (Trolox)/100 g DM in the Purple leaf extract. In this case, high correlation coefficients were also found between the applied methods of testing the antioxidant activity and the total polyphenolic content. Only for the Beauregard cultivar did the correlation coefficients between antioxidant activity assays $\left(\mathrm{ABTS}^{\circ+}, \mathrm{DPPH}, \mathrm{FRAP}\right)$ and general polyphenols turn out to be insignificant (Pearson correlation $\mathrm{R} 2=-0.395, \mathrm{R} 2=-0.369, \mathrm{R} 2=-0.381$, respectively). Antioxidant activity assays of extracts of leaves harvested at $\mathrm{BBCH}$ stage 89 showed the highest and the lowest antioxidant activity in the leaves of the 
Radiosa and Satsumo Imo cultivars, respectively. Xu et al. [27] tested 116 cultivars of sweet potato and found that the total share of phenolic acids amounted to $79.6 \%$ of the total polyphenolic content. According to Padda and Picha [24], the antioxidant activity of sweet potato leaves is differentiated by growth stages. In their research, the authors achieved the highest antioxidant activity in young unripe leaves of sweet potato, with antioxidant potential expressed as Trolox equivalents measured with the DPPH method amounting to an average of $99.61 \mathrm{mg} \mathrm{g}^{-1} \mathrm{DM}$. The authors also demonstrated that the correlation coefficient between antioxidant activity and total polyphenolic content amounted to 0.98 . A similar high correlation coefficient of $\mathrm{R} 2=0.98$ between antioxidant activity measured with the ABTS and DPPH method was arrived at by Zhang et al. [21] and Fu et al. [28]. On the other hand, Jeng et al. [29] studied sweet potato leaves and observed a tendency toward the age-dependent decreasing antioxidant ability of leaves, and the tendency was confirmed in the conducted antioxidant activity assays: DPPH and FRAP. However, our own research points to something opposite: the highest average antioxidant activity measured in ABTS, DPPH, and FRAP assays was found in the oldest leaves harvested at $\mathrm{BBCH}$ stage 89 , i.e., at full ripeness. Different results were achieved in a research study by Liao et al. [30], who found that the antioxidant activity level of sweet potato leaves was more correlated with the flavonol content than with the general polyphenolic content. Research conducted by Fidrianny et al. [31] showed that the antioxidant activity results of sweet potato leaves are influenced by extraction methods. Their results indicate that alcohol extracts show the highest antioxidant activity expressed in ABTS and DPPH assays.

\subsection{The Polyphenolic Content in Sweet Potato Leaves Depending on the Leaf Growth Stage and Cultivar}

The polyphenolic content in the leaves of the analysed cultivars is presented in Table 3 and Figure 1. The total polyphenolic content was significantly differentiated depending on the cultivar and leaf growth stage. The average content of the identified polyphenolic compounds in the cultivars under study ranged from 148.2 to $14038.6 \mathrm{mg} / 100 \mathrm{~g}^{-1} \mathrm{DM}$ for leaves harvested at BBCH stage 14 .

Table 3. Polyphenols content in sweet potato leaves ( $\left.\mathrm{mg} 100 \mathrm{~g}^{-1} \mathrm{DM}\right)$ depending on the development phase according to the $\mathrm{BBCH}$ (Biologische Bundesanstalt, Bundessortenamt und Chemische Industrie) scale.

\begin{tabular}{|c|c|c|c|c|c|c|c|c|c|c|c|}
\hline \multirow{2}{*}{ Varieties } & \multirow{2}{*}{ BBCH } & \multicolumn{5}{|c|}{ Phenolics Acid } & \multirow{2}{*}{ Sum } & \multicolumn{3}{|c|}{ Flavonoids } & \multirow{2}{*}{ Total } \\
\hline & & 5-CQA & 3-CQA & 4-CQA & 3.4-diCQA & 3.5-diCQA & & Q3GA & Q3GL & Sum & \\
\hline \multirow{4}{*}{ Okinava } & 14 & 223.3 & 9455 & 133.0 & 1322 & 1980 & 13,113 & 173.8 & 751.5 & 925.3 & $14,038.6$ \\
\hline & 51 & 148.6 & 1023 & 112.0 & 15.65 & 50.95 & 1350 & 30.18 & 119.7 & 149.9 & 1500.1 \\
\hline & 89 & 250.3 & 4572 & 272 & 522.3 & 713 & 6330 & 235.2 & 494.8 & 730.0 & 7059.6 \\
\hline & 14 & 184.8 & 1160 & 271.4 & 2.09 & 149.5 & 1768 & $n t$ & $n t$ & $n t$ & 1767.8 \\
\hline \multirow[t]{2}{*}{ Carmen Rubin } & 51 & 52.2 & 507.0 & 113.8 & 49.61 & 44.51 & 767.1 & 23.21 & 38.87 & 62.08 & 829.2 \\
\hline & 89 & 224 & 3386 & 426.8 & 633.2 & 577.0 & 5248 & 210.6 & 875.8 & 1086 & 6333.4 \\
\hline & 14 & 140.27 & 577.9 & 621.3 & 59.39 & 206.0 & 1604.9 & $n t$ & $n t$ & $n t$ & 1604.9 \\
\hline \multirow[t]{2}{*}{ Radiosa } & 51 & 403.79 & 3711 & 402.5 & 73.6 & 120.2 & 4711 & 63.27 & 252.4 & 315.7 & 5026.8 \\
\hline & 89 & 527.44 & 7451 & 611.9 & 540.8 & 1037 & 10,168 & 269.6 & 745.8 & 1015 & $11,183.5$ \\
\hline \multirow{4}{*}{ White Triumph } & 14 & $n t$ & 100 & $n t$ & $n t$ & 48.19 & 148.2 & $n t$ & $n t$ & $n t$ & 148.2 \\
\hline & 51 & 135.8 & 416.9 & 65.44 & 45.27 & 50.87 & 714.3 & 39.63 & 6.85 & 46.48 & 760.8 \\
\hline & 89 & 245.1 & 2855 & 35.98 & 429.9 & 823.2 & 4389 & 18.69 & 394.5 & 413.2 & 4802.4 \\
\hline & 14 & 63.69 & 200.5 & 560.3 & 77.55 & 60.06 & 962.0 & $n t$ & $n t$ & $n t$ & 962.1 \\
\hline \multirow[t]{3}{*}{ Malokai } & 51 & $n t$ & 59.64 & 28.1 & $n t$ & $n t$ & 87.74 & 37.97 & 19.05 & 57.03 & 144.76 \\
\hline & 89 & 51.26 & 2371 & 1475 & 265.7 & 479.6 & 4643 & 195.7 & 355.0 & 550.7 & 5193.3 \\
\hline & 14 & 20.95 & 192.5 & 54.87 & 69.06 & 45.7 & 383.1 & $n t$ & $n t$ & $n t$ & 383.1 \\
\hline \multirow[t]{2}{*}{ Purple } & 51 & $160.2^{\mathrm{BC}}$ & 1372 & 215.5 & 32.58 & 40.61 & 1821 & 20.57 & 162.1 & 182.7 & 2003.6 \\
\hline & 89 & $158.4^{\mathrm{CB}}$ & 2490 & 205.7 & 379.4 & 415.8 & 3649 & 77.59 & 351.6 & 429.2 & 4078.1 \\
\hline \multirow{3}{*}{ Beauregard } & 14 & $145.4^{\mathrm{AB}}$ & 832.5 & 303.9 & 22.22 & 95.89 & 1400 & $n t$ & 26.92 & 26.92 & 1426.8 \\
\hline & 51 & $146.5^{\mathrm{BA}}$ & 1477 & 176.8 & 89.41 & 155.6 & 2046 & 3.41 & 162.6 & 166.0 & 2211.3 \\
\hline & 89 & 156.6 & 6364 & 372.7 & 731.4 & 1060 & 8685 & 94.17 & 524.6 & 618.8 & 9303.5 \\
\hline \multirow{3}{*}{ Jewel } & 14 & 285.09 & 3473 & 193.2 & 323.2 & 506.7 & 4781 & 66.42 & 403.4 & 469.8 & 5251 \\
\hline & 51 & 109.45 & 578.9 & 65.16 & 30.81 & 29.07 & 813.4 & 3.37 & 56.35 & 59.71 & 873.1 \\
\hline & 89 & 379.02 & 5399 & 283.7 & 425.0 & 481.4 & 6969 & 190.0 & 573.1 & 763.1 & 7732.2 \\
\hline \multirow{3}{*}{ Satsumo Imo } & 14 & 54.58 & 559.5 & 54.8 & 73.12 & 58.91 & 800.9 & $n t$ & $n t$ & $n t$ & 800.91 \\
\hline & 51 & 3.93 & 131.34 & 11.24 & 71.99 & 72.66 & 291.2 & 39.93 & 20.26 & 60.19 & 351.35 \\
\hline & 89 & 261.6 & 3527 & 175.0 & 261.5 & 541.2 & 4766 & 74.97 & 485.2 & 560.2 & 5326.5 \\
\hline
\end{tabular}

5-CQA: neochlorogenic acid, 3-CQA: chlorogenic acid, 4-CQA: 4-cryptochlorogenic acid, 3,4-diCQA: 3,4-di-Ocaffeoylqunic acid, 3,5-diCQA: 3,5-di-O-caffeoylqunic acid, Q3GA: quercetin-3-O-galactoside, Q3GL: quercetin-3-O -glucoside. Statistically not significant differences were marked with letters in the varieties A (BBCH 14), B (BBCH 51), $\mathrm{C}$ (BBCH 89). nt-not detected. 


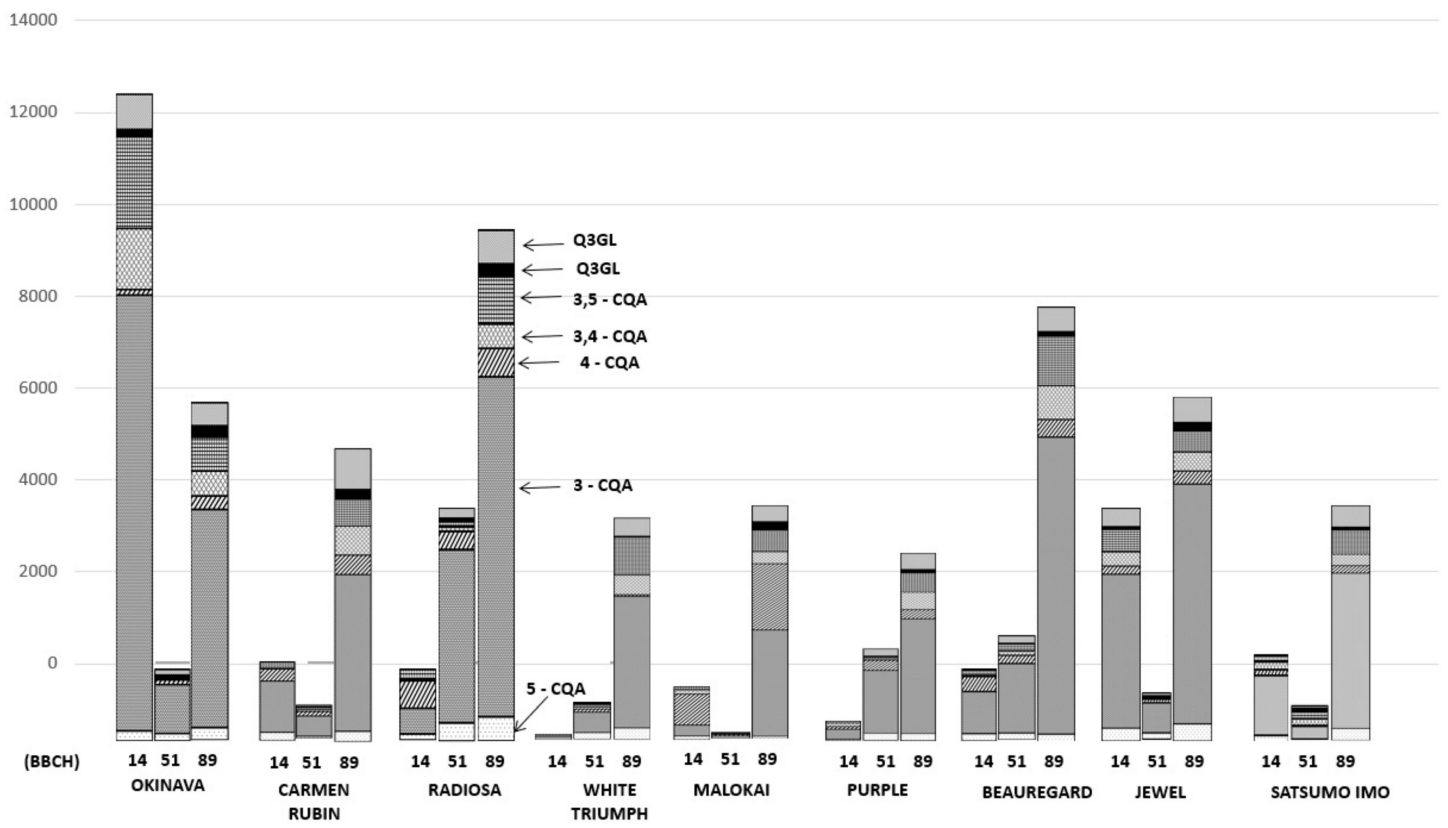

Figure 1. Polyphenol content in sweet potato leaves $\left(\mathrm{mg} / 100 \mathrm{~g}^{-1} \mathrm{DM}\right)$ depending on the development phase according to the $\mathrm{BBCH}$ scale.

In the case of leaves harvested at $\mathrm{BBCH}$ stage 51, the polyphenolic compound concentration ranged from 351.35 to $5026 \mathrm{mg} / 100 \mathrm{~g}^{-1} \mathrm{DM}$, whereas at $\mathrm{BBCH}$ stage 89 , the results varied from 4802.4 to $11.183 .3 \mathrm{mg} / 100 \mathrm{~g}^{-1} \mathrm{DM}$. A summary of the results is presented in Table 3, and a graphic interpretation after statistical processing is shown in Figures 1-4. Our own identification of phenolic acids was corroborated by the research $[19,23,25,29]$. In the research by Jung et al. [32], the dominating compound in sweet potato leaves was 5-neochlorogenic acid (5-CQA), and its amount depended on the genetic properties of cultivars. On the other hand, our own research results point to a significant dominance of chlorogenic acid (3-CQA) in the analysed leaves, in particular those harvested in the last harvest round (BBCH 89). Such results can be caused by different climate and soil conditions during the cultivation of sweet potato in Poland. The concentration of chlorogenic acid (3-CQA) in the analysed samples ranged from $37.38 \%$ in Satsumo Imo leaves harvested at BBCH stage 51 to $69.83 \%$ in Jewel leaves harvested at $\mathrm{BBCH}$ growth stage 89 (Table 3). Li et al. [18] studied phenolic acids in the leaves of 14 sweet potato cultivars and also identified phenolic acids that were not identified in our own research, that is: caffeic acid, ferulic acid, and 4,5-di-CQA. Their results indicate that the total polyphenolic content in leaves ranged from 2640.2 to $4200.9 \mathrm{mg} / 100 \mathrm{~g} \mathrm{~g}^{-1} \mathrm{DM}$, whereas the identified levels of phenolic acids in sweet potato leaves from their own cultivation depended on the cultivar and leaf harvest date and ranged from $13.113 \mathrm{mg} / 100 \mathrm{~g}^{-1} \mathrm{DM}$ in Okinava leaves harvested at BBCH stage 14 to $148.2 \mathrm{mg} / 100 \mathrm{~g}^{-1}$ in White Triumph leaves harvested at the same growth stage. In turn, Sasaki et al. [33] studied the phenolic acid content in leaves of 6 cultivars and 2 lines of sweet potato harvested every month from May to August and obtained the highest concentration of 3,5-di-CQA. Similarly, Truong et al. [23] studied the leaves of 9 sweet potato cultivars and found the highest concentration of 3,5-di-CQA, which depended on the cultivar and leaf growth stage. The amount of phenolic acids in our own leaf samples harvested at $\mathrm{BBCH}$ stage 14 varied from 148.2 to $13.113 \mathrm{mg} / 100 \mathrm{~g}^{-1} \mathrm{DM}$. The lowest value was observed in the White Triumph cultivar, and the highest was observed in Okinava, which was also characterised by the highest content of flavonols in leaves harvested at the same growth stage. The second harvest round of sweet potato leaves took place at BBCH stage 51 (formation of side shoots), and the results of phenolic acid concentration ranged from $87.74 \mathrm{mg} / 100 \mathrm{~g}^{-1} \mathrm{DM}$ in Molokai leaves to $4711 \mathrm{mg} / 100 \mathrm{~g}^{-1} \mathrm{DM}$ in Radiosa leaves. The final harvest round of sweet potato leaves took place at $\mathrm{BBCH}$ stage 89 when they were fully ripe, and the concentration of phenolic acids ranged from $3649 \mathrm{mg} / 100 \mathrm{~g}^{-1} \mathrm{DM}$ in Purple leaves to $10.168 \mathrm{mg} / 100 \mathrm{~g}^{-1} \mathrm{DM}$ in Radiosa leaf samples. The highest concentration of phenolic acids 
was found in leaves harvested at full ripeness, i.e., at BBCH stage 89. A similar relation was found in a research study by Jaakola et al. [34], with the highest level of flavonoid compounds in the oldest leaves, which was probably caused by longer exposure to UV radiation. The earlier results of Jaakola et al. [34] were corroborated in a research study by Carvalho et al. [35], pointing to the higher concentration of polyphenolic compounds in leaves exposed to longer UV radiation $(16 \mathrm{~h})$ as compared to leaves exposed to UV light only for $8 \mathrm{~h}$. Padda and Picha [24] and Jenga et al. [29] studied leaves of various sweet potato cultivars at different growth stages and found a significantly higher concentration of phenolic acids in young leaves; however, this was not confirmed in our own research, in which the highest concentration of polyphenolic compounds was recorded in leaves harvested at BBCH stage 89 . It must be added that the discrepancies between the results can be caused by cultivar differentiation and cultivation in different climate conditions with lower temperatures. Research by Islam et al. [36] confirmed that high exposure to the sun and lower temperature during vegetation is conducive to higher levels of phenolic acids in sweet potato leaves.

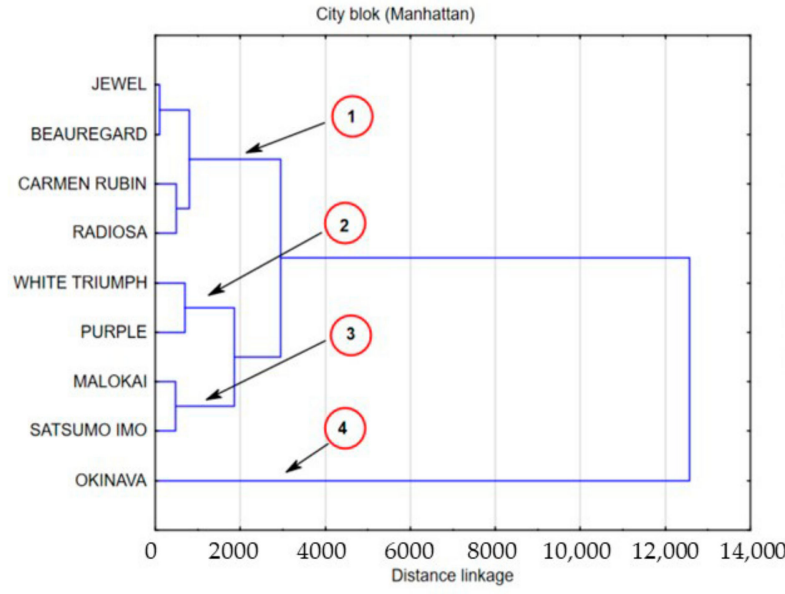

(a)

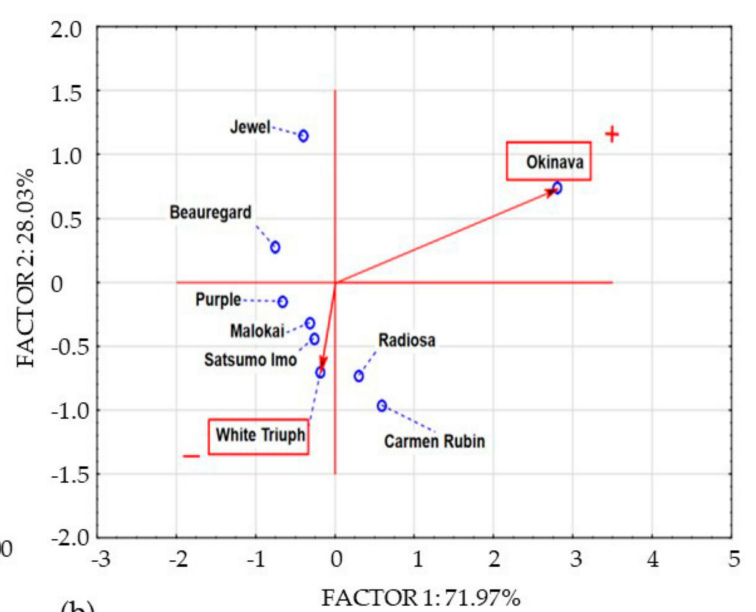

(b)

Figure 2. Dendrogram and bio-plot (PCA) of average concentrations of polyphenols in sweet potato leaves collected in $\mathrm{BBCH}$ phase 14. (a) 1,2,3,4 clusters. (b) + variety with the highest concentration polyphenolics compounds, - variety with the lowest concentration polyphenolics compounds.

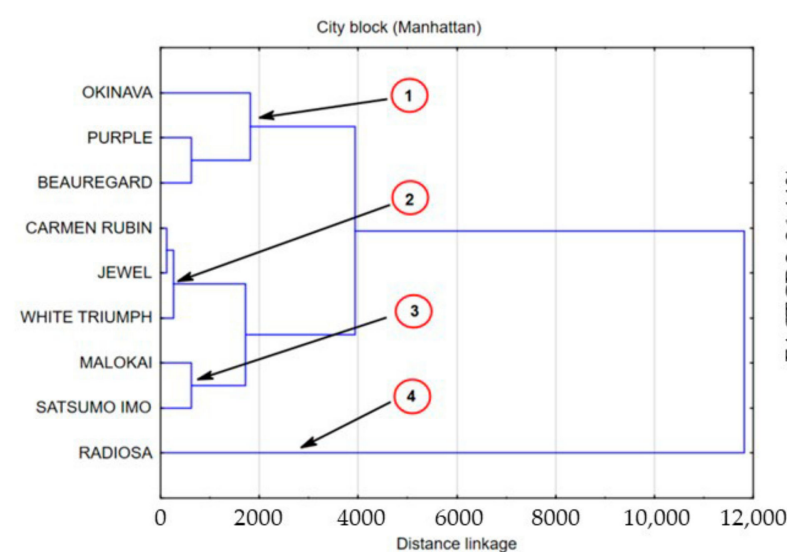

(a)

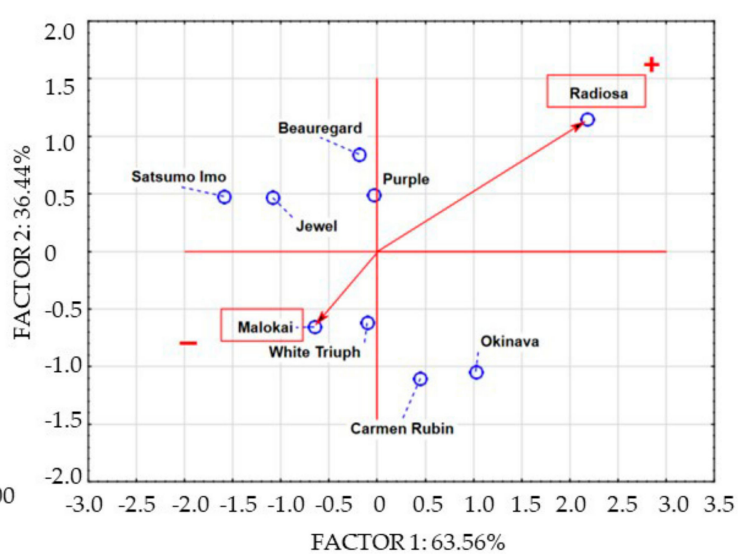

(b)

Figure 3. Dendrogram and bio-plot (PCA) of average concentrations of polyphenols in sweet potato leaves collected in $\mathrm{BBCH}$ phase 51. (a) 1,2,3,4 clusters. (b) + variety with the highest concentration polyphenolics compounds, - variety with the lowest concentration polyphenolics compounds. 


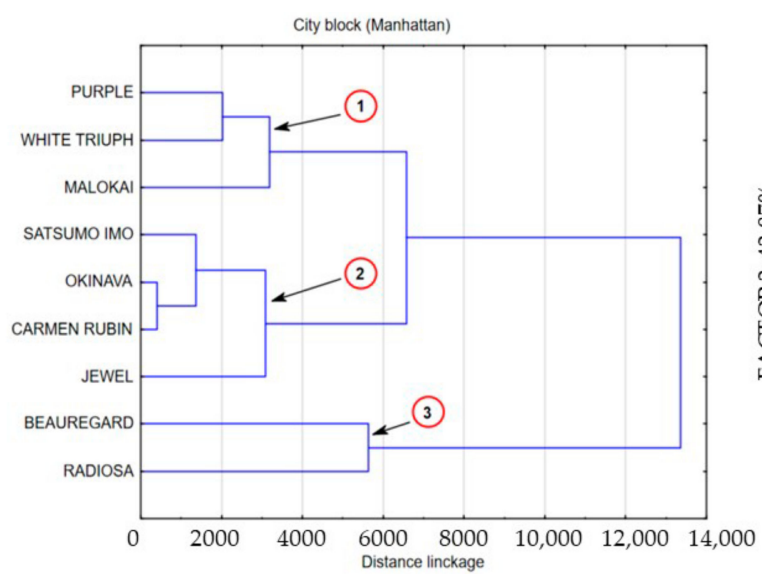

(a)

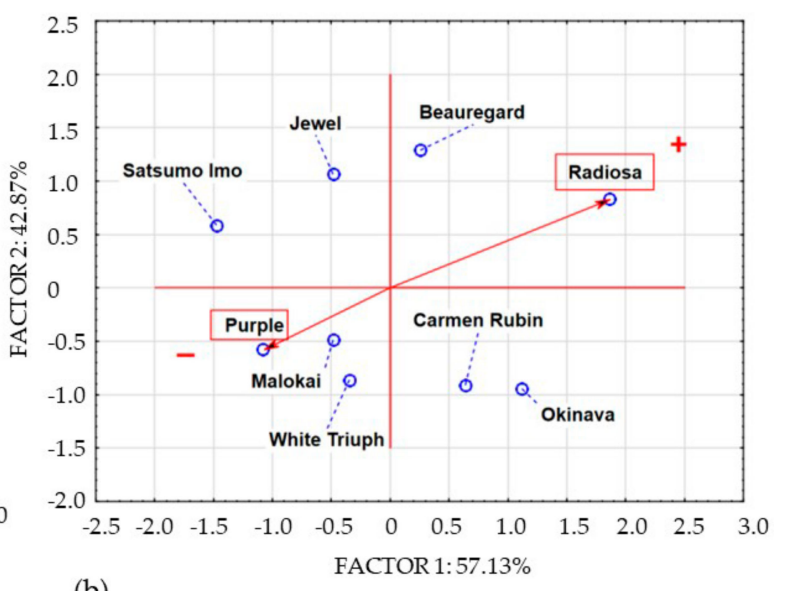

(b)

Figure 4. Dendrogram and bio-plot (PCA) of average concentrations of polyphenols in sweet potato leaves collected in $\mathrm{BBCH}$ phase 89. (a) 1,2,3,4 clusters. (b) + variety with the highest concentration polyphenolics compounds, - variety with the lowest concentration polyphenolics compounds.

As in the case of phenolic acids, the concentration of the measured flavonoids was differentiated by the physiological age of the test material and the genetic properties of the cultivars under study. In the first harvest round, at $\mathrm{BBCH}$ stage 14, the flavonol content in the sweet potato leaf samples was very differentiated. Nevertheless, in most cases, the measured flavonol content was below the detection limit. Flavonoid compounds were only detected in the Okinava, Beauregard, and Jewel cultivars. Their concentration ranged from $26.92 \mathrm{mg} / 100 \mathrm{~g}^{-1} \mathrm{DM}$ in Jewel leaves to $925.3 \mathrm{mg} / 100 \mathrm{~g}^{-1} \mathrm{DM}$ in Okinava leaves, as shown in Table 2. At BBCH growth stage 51, the presence of flavonoids was found in the leaves of all cultivars under study. The concentration of flavonoids varied from $46.48 \mathrm{mg} / 100 \mathrm{~g}^{-1} \mathrm{DM}$ in the White Triumph leaf material to $315.7 \mathrm{mg} / 100 \mathrm{~g}^{-1} \mathrm{DM}$ in Radiosa leaves. A much higher flavonol concentration was measured at full ripeness (BBCH 89), ranging from $413.2 \mathrm{mg} / 100 \mathrm{~g}^{-1} \mathrm{DM}$ in White Triumph leaves to $1086 \mathrm{mg} / 100 \mathrm{~g}^{-1} \mathrm{DM}$ in Carmen Rubin leaves. The results of our own study indicate a significant differentiation of flavonol content in sweet potato leaves depending on the cultivar. This was confirmed in a research study by Ojong et al. [37], which points to the significant differentiation of flavonol compound content in sweet potato leaves depending on the cultivar. The statistical analysis based on the Anova test showed a statistically significant differentiation of phenolic acid and flavonol content depending on the harvest date in the leaves of all cultivars under study. The agglomeration of data on the spatial structure of total polyphenolic compounds in the leaves of the cultivars under study with multivariate statistical analysis enabled the formation of groups characterised by common variety. The new data structure was created on the basis of the analysis of clusters and principal components presented in Figures 2-4, which contain a graphic interpretation of the new data structure. Figure 2a,b presents an aggregation of polyphenolic compound concentration in the leaves under study at the first growth stage (BBCH 14)

Intergroup relations reveal five main clusters characterised by shared variance. Cluster 1 contains data describing the polyphenolic compound concentration in Jewel and Carmen Rubin leaves; cluster 2 contains the polyphenolic compound concentration in Beauregard and Radiosa cultivars. Cluster 3 includes the polyphenolic compound concentration in White Triumph and Purple leaves, whereas cluster 4 includes the aggregation of variables describing the total polyphenolic compounds in Molokai and Satsumo Imo cultivars. Cluster 5 contains a single element referring to the total polyphenols in Okinava leaves. Cluster 3 can be considered a formation characterised by a concentration of total polyphenols in leaves at the lowest average level of $265.6 \mathrm{mg} / 100 \mathrm{~g}^{-1} \mathrm{DM}$. Cluster 3 is most related to cluster 4 with an average level of polyphenolic compounds in the samples under study amounting to $881.4 \mathrm{mg} / 100 \mathrm{~g}^{-1} \mathrm{DM}$. The aggregation of factors making up cluster 1 contained polyphenolic compounds from sweet potato leaves at an average level of $1515 \mathrm{mg} / 100 \mathrm{~g}^{-1} \mathrm{DM}$. The concentration of 
polyphenolic compounds included in cluster 2 (polyphenols in Beauregard and Radiosa leaves) was 13 times higher than the polyphenol level in cluster 3, on average amounting to $3509 \mathrm{mg} / 100 \mathrm{~g}^{-1} \mathrm{DM}$. The single-element cluster 5 shows an exceptionally high concentration of polyphenolic compounds in Okinava leaves amounting to $14.038 \mathrm{mg} / 100 \mathrm{~g}^{-1} \mathrm{DM}$. The data structure shaping the concentration of polyphenolic compounds in the leaves of 9 sweet potato cultivars at $\mathrm{BBCH}$ growth stage 51 enables their aggregation. Based on cluster analysis and principal component analysis (PCA), we created a spatial image of the variable system, which is presented in Figure 3a,b.

The obtained data structure points to four areas of shared data variance. The space of the first area was filled with the concentration of polyphenols in Okinava, Purple, and Beauregard leaves. The cluster of the second area was formed by data describing the polyphenolic compound concentrations in leaves of cultivars with a similar polyphenolic compound concentration, including the following cultivars: Carmen Rubin, Jewel, and White Triumph. The polyphenol content in Molokai and Satsumo Imo leaves was included in cluster 3. Cluster 4 is a single-element subset that contains the concentration of polyphenolic compounds in the Radiosa leaves. Sweet potato leaves harvested at BBCH stage 51 demonstrated a varied concentration of polyphenolic compounds. The leaves of the Radiosa, White Triumph, Purple, and Beauregard cultivars demonstrated a statistically significant increase in the level of polyphenolic compounds as compared to the average concentration of polyphenols in the leaves of the 9 sweet potato cultivars under study, whereas the leaves of Okinava, Carmen Rubin, White Triumph, Molokai, Jewel, and Satsumo Imo were characterised by a statistically significant decrease of the polyphenol content as compared to samples collected at $\mathrm{BBCH}$ stage 14 . The average lowest measured content of polyphenolic compounds in leaves at BBCH stage 51 was located in cluster 3, which included Molokai and Satsumo Imo leaves, with their level similar to White Triumph and Purple leaves harvested at $\mathrm{BBCH}$ stage 14 and amounting to $248 \mathrm{mg} / 100 \mathrm{~g} \mathrm{~g}^{-1} \mathrm{DM}$. Cluster 2 presents a group of average polyphenol concentration of $821 \mathrm{mg} / 100 \mathrm{~g}^{-1} \mathrm{DM}$, including Carmen Rubin, Jewel, and White Triumph leaves, with an average measured content of the compounds that was 3.3 times higher than that in cluster 3. Data exploration of the polyphenol concentration in Okinava, Purple, and Beauregard leaves formed cluster 1, with the average polyphenolic compound content of $1905 \mathrm{mg} / 100 \mathrm{~g} \mathrm{~g}^{-1} \mathrm{DM}$, which is 7.7 times higher than the polyphenol concentration in cluster 3. Clearly, as compared to the other cultivars, Radiosa leaves had the highest concentration of polyphenols amounting to $5027 \mathrm{mg} / 100 \mathrm{~g}^{-1} \mathrm{DM}$, which is 20 times higher than the concentration of polyphenolic compounds in cluster 3. Sweet potato leaves harvested at full ripeness, that is at BBCH stage 89, contained an average concentration of polyphenols of $6779 \mathrm{mg} / 100 \mathrm{~g} \mathrm{~g}^{-1} \mathrm{DM}$, which in comparison to previous harvest rounds that involved an increase in the polyphenolic compound content by $56.76 \%$ and $77.54 \%$ for BBCH growth stages 14 and 51, respectively. Statistical analysis of our own research results based on cluster analysis and principal component analysis enabled the categorisation of three main agglomerations marked on Figure 4a,b as clusters 1, 2, and 3.

Cluster 1, with an average level of polyphenolic compounds of $4691 \mathrm{mg} / 100 \mathrm{~g}^{-1} \mathrm{DM}$, included Purple, White Triumph, and Molokai leaves. Data aggregation describing the coessentiality of data contained in cluster 2 with an average polyphenolic compound content of $6613 \mathrm{mg} / 100 \mathrm{~g}^{-1} \mathrm{DM}$, included Satsumo Imo, Okinava, Carmen Rubin, and Jewel leaves. Variable aggregation describing the polyphenolic compound concentration in Radiosa and Beauregard leaves formed cluster 1, with an average concentration of polyphenols of $10.243 \mathrm{mg} / 100 \mathrm{~g}^{-1} \mathrm{DM}$.

\section{Materials and Methods}

\subsection{Reagents and Standards}

Acetonitrile, acetic acid, methanol, ABTS (2,2'-azino-bis(3-ethylbenzothiazoline-6-sulfonic acid), Trolox (6-hydroxy-2,5,7,8-tetramethylchroman-2-carboxylic acid), TPTZ (2,4,6-Tris(2-pyridyl)-s -triazine), and DPPH (2,2-Diphenyl-1-picrylhydrazyl) were purchased from Sigma-Aldrich (Steinheim, 
Germany). Chlorogenic acid, quercetin-3-o-glucoside, and quercetin-3-o-galactoside were purchased from Extrasynthese (Lyon, France).

\subsection{Plant Materials}

The research was based on a rigorous field experiment conducted with the use of a random blocks method between 2016-2018 in Żyznów, Poland (49 $49^{\prime} \mathrm{N}$ or $\left.21^{\circ} 50^{\prime} \mathrm{E}\right)$. The experiment was conducted in three replicates on defective wheat complex soil with slightly acidic $\mathrm{pH}(6.0-6.5 \mathrm{pH}$ in $\mathrm{KCl})$. In the subsequent research years, soils did not differ in terms of the content of organic matter or macronutrient absorption. The average content of organic matter ranged from 15.0 to $18.7 \mathrm{~g} \cdot \mathrm{kg}^{-1}$. The content of absorbable phosphorus was $68.6-110 \mathrm{mg} \cdot \mathrm{P} \cdot \mathrm{kg}^{-1}$, potassium $139-149 \mathrm{mg} \cdot \mathrm{K} \cdot \mathrm{kg}^{-1}$, and magnesium $50-55 \mathrm{mg} \cdot \mathrm{Mg} \cdot \mathrm{kg}^{-1}$. Nitrogen fertilisation was used simultaneously to NPK fertilisation in the following amounts: $80 \mathrm{~kg} \cdot \mathrm{N} ; 34.9 \mathrm{~kg} \cdot \mathrm{P} ; 99.6 \mathrm{~kg} \cdot \mathrm{K} \cdot \mathrm{ha}^{-1}$, and $25 \mathrm{t} \cdot \mathrm{ha}^{-1}$ of manure. Manure fertilisation was used in the autumn, whereas mineral fertilisation was used in the spring, prior to planting. The propagating material included rooted cuttings of sweet potato from in vitro propagation. They were planted with $40 \times 75 \mathrm{~cm}$ spacing in mid-May. The size of crop plots was $15 \mathrm{~m}^{2}$. During vegetation, cultivation was carried out in accordance with normal agricultural practice. The experiment had a two-factorial design. Factor 1 included sweet potato growth stages-their codes followed the BBCH scale (Biologische Bundesanstalt, Bundessortenamt und Chemische Industrie) [38]: main stem growth (stage 14), side shoot growth (stage 51), full ripeness (stage 89). Factor 2 included sweet potato cultivars (Okinava, Carmen Rubin, Radiosa, White Triumph, Molokai, Purple, Beauregard, Jewel, and Satsumo Imo). After each leaf harvest, the leaves were dried until solid in the lab dryer Alpha 1-2 LD plus.

\subsection{Extraction Procedure}

The finely powdered samples $(1 \mathrm{~g})$ were extracted with $10 \mathrm{~mL}$ of methanol acidified with $1 \%$ acetic acid. The extraction was performed twice by incubation for 20 min under sonication and with occasional shaking. Next, the slurry was centrifuged at 10,000 rpm for $10 \mathrm{~min}$, and the supernatant was filtered through a $0.45-\mu \mathrm{m}$ membrane and used for further chromatographic analysis.

\subsection{Determination of Polyphenolic Compounds}

Polyphenolic compounds were analysed using an ultra-performance reverse-phase liquid chromatography (UPLC)-PDA-MS/MS Waters ACQUITY system (Waters, Milford, MA, USA), consisting of a binary pump manager, sample manager, column manager, photodiode array (PDA) detector, and tandem quadrupole mass spectrometer (TQD) with electrospray ionisation (ESI). The separation was carried out using a BEH C18 column $(100 \mathrm{~mm} \times 2.1 \mathrm{~mm}$ i.d., $1.7 \mu \mathrm{m}$, Waters USA) kept at $50{ }^{\circ} \mathrm{C}$. For the anthocyanins investigation, the following solvent system was applied: mobile phase A ( $2 \%$ formic acid in water $v / v)$ and mobile phase B ( $2 \%$ formic acid in $40 \%$ ACN in water $v / v)$. For other polyphenolic compounds, a lower concentration of formic acid was used $(0.1 \% v / v)$. The gradient program was set as follows: $0 \mathrm{~min} 5 \% \mathrm{~B}$, from 0 to 8 min linear to $100 \% \mathrm{~B}$, and from 8 to $9.5 \mathrm{~min}$ for washing and back to initial conditions. The injection volume of the samples was $5 \mu \mathrm{L}$ (partial loop with needle overfill), and the flow rate was $0.35 \mathrm{~mL} / \mathrm{min}$. The following parameters were used for TQD: capillary voltage, $3.5 \mathrm{kV}$; con voltage, $30 \mathrm{~V}$ in positive and negative mode; the source was kept at $120^{\circ} \mathrm{C}$, and the desolvation temperature was $350^{\circ} \mathrm{C}$; con gas flow, $100 \mathrm{~L} / \mathrm{h}$; and desolvation gas flow, $800 \mathrm{~L} / \mathrm{h}$. Argon was used as the collision gas at a flow rate of $0.3 \mathrm{~mL} / \mathrm{min}$. The polyphenolic detection and identification were based on a specific PDA spectra, mass-to-charge ratio, and fragment ions obtained after collision-induced dissociation (CID). Quantification was achieved by the injection of solutions of known concentrations ranging from 0.05 to $5 \mathrm{mg} / \mathrm{mL}$ of phenolic compounds as standards. All determinations were performed in triplicate and expressed as $\mathrm{mg} / \mathrm{L}$. Waters MassLynx software v.4.1 was used for data acquisition and processing. 


\subsection{Ferric-Reducing/Antioxidant Power Assay}

The total antioxidant potential of the samples under study was measured with the FRAP method based on the reducing power of the compound (aqueous solution of iron salt) as the indicator of the antioxidant power [39]. A potential antioxidant reduces a ferric ion $\left(\mathrm{Fe}^{3+}\right)$ to a ferrous ion $\left(\mathrm{Fe}^{2+} / \mathrm{TPTZ}\right)$, forming a blue complex created as a result of antioxidants giving up electrons at $\mathrm{pH}$ 3.6. The reaction is monitored by absorbance assay at $593 \mathrm{~nm}$. The iron-reducing reagent antioxidant (FRAP) was obtained by mixing $300 \mathrm{mM}$ acetate buffer and $10 \mathrm{~mL}$ of TPTZ in $40 \mathrm{mM} \mathrm{HCl}$ and $20 \mathrm{mM} \mathrm{FeCl} 3.6 \mathrm{H}_{2} \mathrm{O}$ with a 10:1:1 ratio $(v / v / v)$ at $37^{\circ}$. The freshly prepared active FRAP reagent was pipetted with a $1-5 \mathrm{~mL}$ variable micropipette $(3.995 \mathrm{~mL})$, mixed with $5 \mu \mathrm{L}$ of appropriately diluted plant sample, and thoroughly mixed. An intense blue colour appeared when the iron-tripyridyltriazine (Fe $\left.{ }^{3+} \mathrm{TPTZ}\right)$ complex was reduced to a ferrous form $\left(\mathrm{Fe}^{2+}\right)$, and absorbance at $593 \mathrm{~nm}$ was recorded in comparison to a blank feed of the reagent $\left(3.995 \mathrm{~mL}\right.$ of reagent FRAP $+5 \mu \mathrm{L}$ distilled water) after 30 min incubation at $37^{\circ}$. All measurements were taken in three replicates. The standard curve was delineated with the use of various Trolox concentrations. All solutions were used on the day they were prepared. The results were corrected to account for dilution and expressed in $\mu \mathrm{mol}$ of Trolox equivalent per $100 \mathrm{~g}$ DM of the sample. The tests were carried out by means of the Thermo EVO 300PC Spectrophotometer (Thermo, Waltham, MA, USA).

\subsection{Free Radical Scavenging Ability Determination Using a Stable ABTS Radical Cation}

The free radical scavenging ability in plant samples was determined by means of the ABTS radical cation decolourisation assay [40]. An ABTS ${ }^{+}$radical cation was obtained in a reaction between $7 \mathrm{mM}$ ABTS. ${ }^{+}$in water and $2.45 \mathrm{mM}$ potassium persulphate (1:1) stored in darkness at room temperature for 12-16 h prior to use. Then, the ABTS ${ }^{+}$solution was diluted with methanol until an absorbance of 0.700 at $734 \mathrm{~nm}$ was obtained. After adding $5 \mu \mathrm{L}$ of plant extract to $3.995 \mathrm{~mL}$ of the diluted ABTS. ${ }^{+}$solution, absorbance was measured after $10 \mathrm{~min}$ from initial mixing. Each assay included an appropriate blind solvent. For all analyses, a standard curve was drawn based on various Trolox concentrations. All measurements were taken in three replicates with the use of the Thermo EVO 300PC Spectrophotometer (USA). The results were corrected to account for dilution and expressed in $\mu \mathrm{mol}$ of Trolox per $100 \mathrm{~g}$ of DM.

\section{7. $D P P H$}

The total ability to scavenge free radicals in the sweet potato leaf samples under study was estimated on the basis of a slightly modified method by [41] with the use of a stable DPPH free radical with a maximum absorption at $515 \mathrm{~nm}$. The radical solution was prepared by dissolving $2.4 \mathrm{mg}$ DPPH in $100 \mathrm{~mL}$ of methanol. The test solution $(5 \mu \mathrm{L})$ was added to $3.995 \mathrm{~mL}$ methanolic DPPH. The mixture was shaken well and kept in darkness at room temperature for $10 \mathrm{~min}$. Absorbance of the reaction mixture was measured spectrophotometrically at $515 \mathrm{~nm}$. In addition, absorbance of free radical DPPH without antioxidant was measured, i.e., in a blind feed. DPPH ${ }^{\bullet}$ tests were conducted in three replicates. The results were corrected to account for dilution and calculated on the basis of a curve formed from various Trolox concentrations, and the end result was expressed in $\mu \mathrm{m}$ of Trolox per $100 \mathrm{~g}$ DM.

\subsection{Statistical Analysis}

The results were presented as an average of three independent measurements. All analyses were carried out in the Statistica v. 13.3 software (StatSoft, Kraków, Poland). The significance of averages was tested with a post-hoc procedure in Duncan test, which is a part of one-way analysis of variance (ANOVA). Correlation analysis was conducted with Pearson two-way correlation. Differences of $p<0.05$ were considered significant. In order to describe mutual relations between test objects, variable reduction techniques were applied: PCA and cluster analysis. 


\section{Conclusions}

The leaves of nine sweet potato varieties grown in a temperate climate in south-eastern Poland contained 7 polyphenolic compounds, including 5 chlorogenic acids (5-CQA, 3-CQA, 4-CQA, 3,4-CQA, 3,5-CQA) and 2 flavonoids (Q3GA, Q3GL). Their content depended on the genetic properties of the cultivars under study and the growth stage of the leaves harvested at various $\mathrm{BBCH}$-scale growth stages: 14,51 , and 89 . The average content of the identified polyphenolic compounds in the varieties under study ranged from $148.2 \mathrm{mg} / 100 \mathrm{~g}^{-1} \mathrm{DM}$ (White Triumph) to $14.038 .6 \mathrm{mg} / 100 \mathrm{~g}^{-1} \mathrm{DM}$ (Okinava) for leaves harvested at $\mathrm{BBCH}$ stage 14. In the case of leaves harvested at $\mathrm{BBCH}$ stage 51 , the polyphenolic compound concentration ranged from $1500.1 \mathrm{mg} / 100 \mathrm{~g}^{-1} \mathrm{DM}$ (Okinava) to $5026.8 \mathrm{mg} / 100 \mathrm{~g}^{-1} \mathrm{DM}$ (Radiosa), whereas at BBCH stage 89 , the results varied from $4078.1 \mathrm{mg} / 100 \mathrm{~g}^{-1} \mathrm{DM}$ (Purple) to $11.183 .5 \mathrm{mg} / 100 \mathrm{~g}^{-1} \mathrm{DM}$ (Radiosa). Carmen Rubin leaves harvested at growth stage 14 were characterised by the highest content of polyphenolic compounds, whereas Okinava leaves had the highest amount of said compounds at growth stage 51 . The highest level of polyphenolic compounds in leaves at the last growth stage, i.e., $\mathrm{BBCH} 89$, was found in the Radiosa cultivar. The average highest activity of bioactive compounds was found in leaves harvested at stage 89 according to the $\mathrm{BBCH}$ scale. The highest concentration levels were found for 3-CQA at all $\mathrm{BBCH}$ growth stages. In most cases, significant correlations were determined between the content of polyphenols and antioxidant activity measured by means of ABTS, DPPH, and FRAP assays. The research confirms that sweet potato leaves are a source of bioactive substances; however, their content is strongly influenced by the genetic properties of the varieties and leaf development phases. The conducted studies contribute to a general understanding of the influence of leaf development phases and genotype on the accumulation of polyphenolic compounds. The results are innovative and can have a practical application, as the knowledge of the content of the substances under study makes it possible to determine the optimal management practice of sweet potato leaf harvest in order to obtain more top-quality raw material.

Author Contributions: Conceptualisation, B.K.-M. and T.C.; Data curation, B.K.-M. and T.C.; Formal analysis, B.K.-M., T.C. and I.K.; Funding acquisition B.K.-M.; Methodology, I.K., T.C, J.O. and B.K.-M.; Supervision, B.K.-M., T.C., I.K., J.K., N.Ż.; Writing-original draft, T.C., B.K.-M. Writing-review and editing, B.K.-M., T.C. and I.K. All authors have read and agreed to the published version of the manuscript.

Funding: This research were financed as part of a scholarship from the Scholarship Fund of Stanisława Pigon for students and employees of the State Higher Vocational School in Krosno with the number PWSZ. 273.05.2018.

Conflicts of Interest: The authors declare no conflicts of interest.

\section{References}

1. Pasqui, M.; Di Giuseppe, E. Climate change, future warming, and adaptation in Europe. Anim. Front. 2019, 9, 6-11. [CrossRef] [PubMed]

2. Mishra, N.; Mohanty, T.R.; Ray, M.; Das, S. Effect of Date of Planting on Growth, Yield and Economics of Sweet Potato (Ipomoea batatas L.) Varieties in Keojhar District of Odisha, India. Int. J. Curr. Microbiol. Appl. Sci. 2019, 8, 2224-2229. [CrossRef]

3. Food and Agriculture Organization of the United Nations. FAOSTAT Statistics Database. Rome, Italy: FAO. 2018. Available online: http://www.fao.org/faostat/en/\#data/QC (accessed on 21 March 2020).

4. Musilová, J.; Bystrická, J.; Árvay, J.; Harangózo, L. Polyphenols and phenolic acids in sweet potato (Ipomoea batatas L.) roots. Potravinarstvo 2017, 11, 82-87. [CrossRef]

5. Krochmal-Marczak, B.; Sawicka, B.; Tobiasz-Salach, R. Impact of cultivations technology on the yield of sweet potato (Ipomoea batatas (L.) Lam) tubers. Emi. J. Food Agric. 2018, 30, 978-983. [CrossRef]

6. Krochmal-Marczak, B.; Sawicka, B.; Michałek, W. Photosynthetic Efficiency in Sweet Potato (Ipomoea batatas L. (Lam)) under Different Nitrogen Fertilization Regimes. Int. J. Agric. Biol. 2019, 22, 627-632. [CrossRef]

7. Gupta, S.; Pareek, S.; Ameta, K.D.; Sarolia, D.K.; Pilania, S.; Kaushik, R.A.; Shuklaand, K.B.; Kumari, P. Analysis of nutritional composition of sweet potato vines. Int. J. Pharm. Phytochem. 2018, 7, 104-106.

8. Dinu, M.; Soare, R.; Băbeanu, C.; Hoza, G. Analysis of nutritional composition and antioxidant activity of sweet potato (Ipomoea batatas L.) leaf and petiole. J. Appl. Bot. Food Qual. 2018, 91, 120-125. [CrossRef] 
9. Ishida, H.; Suzuno, H.; Sugiyama, N.; Innami, S.; Tadokoro, T.; Maekawa, A. Nutritive evaluation on chemical components of leaves, stalks and stems of sweet potatoes liu (Ipomoea batatas Poir). Food Chem. 2000, 68, 359-367. [CrossRef]

10. Sun, H.; Mu, T.; Xi, L.; Zhang, M.; Chen, J. Sweet potato (Ipomoea batatas L.) leaves as nutritional and functional foods. Food Chem. 2014, 156, 380-389. [CrossRef]

11. Johnson, M.; Pace, R.D. Sweet potato leaves: Properties and synergistic interactions that promote health and prevent disease. Nutr. Rev. 2010, 68, 604-615. [CrossRef]

12. Neela, S.; Fanta, S.W. Review on nutritional composition of orange-fleshed sweet potato and its role in management of vitamin A deficiency. Food Sci. Nutr. 2019, 7, 1920-1945. [CrossRef] [PubMed]

13. Mohanraj, R.; Sivasankar, S. Sweet Potato (Ipomoea batatas [L.] Lam)-A Valuable Medicinal Food: A review. J. Med. Food 2014, 17, 1-9. [CrossRef] [PubMed]

14. Zhang, C.; Liu, D.; Wu, L.; Zhang, J.; Li, X.; Wu, W. Chemical charecterization and antioxidant properties of ethanolic extract and its fractions from sweet potato (Ipomoea batatas L) leaves. Foods 2019, 9, 15. [CrossRef] [PubMed]

15. Lee, C.L.; Lee, S.L.; Chen, C.J.; Chen, H.C.; Kao, M.C.; Li, C.H.; Chen, J.Y.; Lai, Y.T.; Wu, Y.C. Characterization of Secondary Metabolites from Purple Ipomoea batatas Leaves and Their Effects on Glucose Uptake. Molecules 2016, 21, 745. [CrossRef] [PubMed]

16. Wang, S.; Nie, S.; Zhu, E. Chemical constituents and health effects of sweet potato. Food Res. Int. 2016, 89, 90-116. [CrossRef]

17. Kurata, R.; Adachi, M.; Yamakawa, O.; Yasimoto, M. Growh Suppresion of Human Xancer Cells by Polyphenolics from Sweetpotato (Ipomoea batatas L.) Leaves. J. Agric. Food Chem. 2007, 55, 185-190. [CrossRef]

18. Li, M.; Jang, G.Y.; Lee, S.H.; Kim, M.Y.; Hwang, S.G.; Sin, H.M.; Kim, H.S.; Lee, J.; Jeong, H.S. Comparison of functional components in various sweet potato leaves and stalks. Food Sci. Biotechnol. 2017, 26, 97-103. [CrossRef]

19. Luo, C.; Wang, X.; Gao, G.; Wang, L.; Li, Y.; Sun, C. Identification and quantification of free, conjugate and total phenolic compounds in leaves of 20 sweet potato cultivars by HPLC-DAD and HPLC-ESI-MS/MS. Food Chem. 2013, 141, 2697-2706. [CrossRef]

20. Li, J.Y; Dong, G.P.; Li, M.L.; Liu, Z.H.; Lu, Y. Efficient counter-current chromatographic isolation and structural identification of phenolic compounds from sweet potato leaves. J. Liq. Chromatogr. R. T. 2012, 35, 1517-1527. [CrossRef]

21. Zhang, L.; Tu, Z.; Wang, H.; Fu, Z.; Wen, Q.; Chang, H.; Uang, X. Comparison of different methods for extracting polyphenols from Ipomoea batatas leaves, and identification of antioxidant constituents by HPLC-QTOF-MS2. Food Res. Int. 2015, 70, 101-109. [CrossRef]

22. Ghasemzadeh, A.; Omidvar, V.; Jaafar, Z.H. Polyphenolic content and their antioxidant activity in leaf extract of sweet potato (Ipomoea batatas). J. Med. Plants Res. 2012, 6, 2971-2976. [CrossRef]

23. Truong, V.D.; McFeeters, R.F.; Thompson, R.T.; Dean, L.L.; Shofran, B. Phenolic acid content and composition in leaves and roots of common commercial sweet potato (Ipomoea batatas L.) cultivars in the United States. J. Food Sci. 2007, 72, 343-349. [CrossRef] [PubMed]

24. Padda, M.S.; Picha, D.H. Antioxidant activity and phenolic composition in 'Beauregard' sweetpotato are affected by root size and leaf age. J. Am. Soc. Hortic. Sci. 2007, 132, 447-451. [CrossRef]

25. Jang, Y.; Koh, E. Antioxidant content and activity in leaves and petioles of six sweet potato (Ipomoea batatas L.) and antioxidant properties of blanched leaves. Food Sci. Biotechnol. 2019, 28, 337-345. [CrossRef]

26. Hue, S.M.; Nasrulhaq Boyce, A.; Somasundram, C. Antioxidant activity, phenolic and flavonoid contents in the leaves of different varieties of sweet potato (Ipomoea batatas). Aust. J. Crop. Sci. 2012, 6, 375-380.

27. Xu, W.; Liu, L.; Hu, B.; Sun, Y.; Ye, H.; Ma, D.; Zeng, X. TPC in the leaves of 116 sweet potato (Ipomoea Batatas L.) varieties and Pushu 53 leaf extracts. J. Food Compos. Anal. 2010, 23, 599-604. [CrossRef]

28. Fu, Z.F.; Tu, Z.C.; Zhang, L.; Wang, H.; Wen, Q.H.; Huang, T. Antioxidant activities and polyphenols of sweet potato (Ipomoea batatas L.) leaves extracted with solvents of various polarities. Food Biosci. 2016, 15, 11-18. [CrossRef]

29. Jeng, T.L.; Lai, C.; Liao, T.C.; Lin, S.Y.; Sung, J.M. Effects of drying on caffeoylquinic acid derivative content and antioxidant capacity of sweet potato leaves. J. Food Drug Anal. 2015, 23, 701-708. [CrossRef]

30. Liao, W.C.; Lai, Y.-C.; Yuan, M.-C.; Hsu, Y.-L.; Chan, C.-F. Antioxidative activity of water extract of sweet potato leaves in Taiwan. Food Chem. 2011, 127, 1224-1228. [CrossRef] 
31. Fidrianny, I.; Windyaswari, A.S.; Wirasutisna, K.R. Antioxidant Capacities of Various Leaves Extract from Five Colors Varieties of Sweet Potatoes Tubers Using ABTS, DPPH Assays and Correlation with Total Flavonoid, Phenolic, Carotenoid Content. Res. J. Med. Plant. 2013, 7, 130-140. [CrossRef]

32. Jung, J.K.; Lee, S.U.; Kozukue, N.; Levin, C.E.; Friedman, M. Distribution of phenolic compounds and antioxidative activities in parts of sweet potato (Ipomoea batata L.) plants and in home processed roots. J. Food Compos. Anal. 2011, 24, 29-37. [CrossRef]

33. Sasaki, K.; Oki, T.; Kai, Y.; Nishiba, Y.; Okuno, S. Effect of repeated harvesting on the content of caffeic acid and seven species of caffeoylquinic acids in sweet potato leaves. Biosci. Biotech. Bioch. 2015, 79, 1308-1314. [CrossRef] [PubMed]

34. Jaakola, L.; Määttä-Riihinen, K.; Kärenlampi, S.; Hohtola, A. Activation of flavonoid biosynthesis by solar radiation in bilberry (Vaccinium myrtillus L) leaves. Planta 2004, 5, 721-728.

35. Carvalho, I.S.; Cavaco, T.; Carvalho, L.M.; Duque, P. Effect of photoperiod on flavonoid pathway activity in sweet potato (Ipomoea batatas (L.) Lam.) leaves. Food Chem. 2010, 118, 384-390. [CrossRef]

36. Islam, M.S.; Yoshimoto, M.; Ishiguro, K.; Okuno, S.; Yamakawa, O. Effect of artificial shading and temperature on radical scavenging activity and polyphenolic composition in sweet potato (Ipomoea batatas L.) leaves. J. Am. Soc. Hort. Sci. 2003, 128, 182-187. [CrossRef]

37. Ojong, P.B.; Njitiv, V.; Guo, Z.; Gao, H. Variation of flavonoid content among sweetpotato accessions. J. Am. Soc. Hort. Sci. 2008, 133, 819-824. [CrossRef]

38. Hack, V.H.; Bleiholder, H.; Buhr, L.; Meier Schnock-Fricke, U.; Weber, E.; Witzenberger, A. Einheitliche Codierung der phanologischen Entwicklungsstadien mono- und dikotyler Pflanzen-Erweiterte BBCH-Skala, Allgemein. Nachrichtenbl. Deut. Pflanzenschutzd 1992, 44, 265-270.

39. Benzie, I.F.F.; Devaki, M. The ferric reducing/antioxidant power (FRAP) assay for non enzymatic antioxidant capacity: Concepts, procedures, limitations and applications. In Measurement of Antioxidant Activity and Capacity: Recent Trends and Applications; Apak, R., Capanoglu, E., Eds.; Wiley: Hoboken, NJ, USA, 2018; pp. $77-104$.

40. Re, R.; Pellegrini, N.; Proteggente, A.; Pannala, A.; Yang, M.; Rice-Evans, C. Antioxidant activity applying an improved ABTS radical cation decolorization assay. Free Radic. Biol. Med. 1999, 26, 1231-1237. [CrossRef]

41. Nenadis, N.; Tsimidou, M.Z. DPPH (2,2-di (4-tert-octylphenyl)-1-picrylhydrazyl) radical scavenging mixed-mode colorimetric assay(s). In Measurement of Antioxidant Activity and Capacity: Recent Trends and Applications; Apak, R., Capanoglu, E., Eds.; Wiley: Hoboken, NJ, USA, 2018; pp. 141-161.

Sample Availability: Samples of phenolic acids and flavonols in leaves sweet potato (Ipomoea batatas L.) depending on their stage of development are available to the authors (B.K.-M. and T.C.) on request. 